Original Research Paper

\title{
Density and Spread Pattern of Carnivore Plant (Nepenthes spp.) In The Area of Sebomban Hill Bonti District, Sanggau
}

\author{
Ternisius Apriyanto ${ }^{1 *}$, Rafdinal ${ }^{1}$, Sukal Minsas ${ }^{1}$ \\ ${ }^{1}$ Program Studi Biologi, Fakultas MIPA, Universitas Tanjungpura, Jl. Prof. Dr. Hadari Nawawi, \\ Pontianak, Indoneisa
}

\author{
Article History \\ Received : July $28^{\text {th }}, 2021$ \\ Revised : August 27 $7^{\text {th }}, 2021$ \\ Accepted : September $26^{\text {th }}, 2021$ \\ Published : October $07^{\text {th }}, 2021$ \\ *Corresponding Author: \\ Ternisius Apriyanto, \\ Program Studi Biologi, Fakultas \\ MIPA, Universitas Tanjungpura, \\ Pontianak, Indonesia \\ Email:ternisiusapriyanto47@gmai \\ $\underline{1 . c o m}$
}

\begin{abstract}
Nepenthes spp. is kind of plant that arranged ecosystem in West Kalimantan, especially in the Sebomban hill area, Sanggau Regency. But, its existence is threatened so that several species are included in the endangered category according to the Convention on International Trade in Endangered Species (CITES). The research aims to determine species, community structure, anddistribution patterns of Nepenthes spp. in the area of Sebomban hill, Bonti District, Sanggau Regency. The research method used purposive samplingand systematic sampling with transect. The results showed that there are 3 types of Nepenthes spp. namely $N$. ampullaria, $N$. mirabilis and $N$, gracilis. The density value of Nepenthes spp. ranged from $10-45$ individual/ ha. The index of importance value of Nepenthes spp. ranged from $42 \%$ - 134\%, the highest value being Nepenthes ampullaria in location III, while the lowest value was found in location I, namely $N$. gracilis. All Nepenthes spp. those found at the research location have a pattern of distribution as clustered.
\end{abstract}

Keywords: Density; Nepenthes spp.; Distribution's Pattern;

Sebomban

\section{Pendahuluan}

Nepenthes merupakan tumbuhan herba dan dapat tumbuh sebagai liana maupun tumbuh secara terrestrial (Mansur, 2006). Tumbuhan ini dikelompokkan dalam jenis organisme karnivora yang berpotensi sebagai agen pengendali hayati serangga. Nepenthes merupakan salah satu tumbuhan yang dilindungi berdasarkan UndangUndang No. 5 Tahun 1990 tentang konservasi Sumber Daya Alam Hayati dan Ekosistemnya serta Peraturan Pemerintah No. 7 Tahun 1999 tentang Pengawetan Jenis Tumbuhan dan Satwa. Semua jenis Nepenthes dikategorikan dalam status pembatasan dari segala bentuk kegiatan perdagangan (Appendix 2), kecuali Nepenthes rajah dan Nepenthes khasiana yang statusnya dilarang untuk diperdagangkan (CITES, 2010).

Terdapat 139 jenis Nepenthes dan sebagian besar hidup dan tumbuh di Indonesia (68 Jenis, 59 berstatus endemik), 32 jenis diantaranya terdapat di hutan Kalimantan, Sarawak, Sabah, dan Brunei Darussalam (Mansur, 2006). Penelitian Selvi et al (2015) ditemukan tiga jenis Nepenthes yaitu Nepenthes ampullaria, Nepenthes xhookeriana, dan Nepenthes rafflesiana di Kawasan Hutan Lindung Gunung Ambawang Kabupaten Kubu Raya, Kalimantan Barat. Sebanyak tujuh jenis Nepenthes telah didapatkan di Kawasan Hutan Tanaman Industri Kabupaten Mempawah Kalimantan Barat (Septiani et al., 2018).

Tumbuhan Nepenthes spp. juga ditemukan di wilayah kaki bukit Sebomban Desa Upe, Kecamatan Bonti, Kabupaten Sanggau dengan tipe tanah gambut di beberapa lokasi (Data Monografi Desa Upe, 2017). Keberadaan Nepenthes spp. mengalami ancaman yang disebabkan karena penggunaan kekayaan alam yang semakin meningkat seiring bertambahnya populasi manusia di bumi. (Supriatna, 1998). Nepenthes yang berada di kawasan ini sedang 
mengalami ancaman yang cukup serius seperti adanya aktivitas pembukaan lahan pertanian dan perkebunan oleh masyarakat lokal. Sementara itu, data hasil penelitian terkait jenis-jenis Nepenthes spp. dan pola penyebarannya yang terdapat di hutan Sebomban ini belum pernah dilakukan sehingga perlu dilakukan penelitian.

\section{Bahan dan Metode}

Penelitian ini dilakukan pada bulan Agustus-November 2020 di Desa Upe, Kecamatan Bonti, Kabupaten Sanggau. Identifikasi jenis Nepenthes spp. dilakukan di Laboratorium Biologi Fakultas Matematika dan Ilmu Pengetahuan Alam Universitas Tanjungpura.

\section{Deskripsi Lokasi}

Wilayah kaki bukit Sebomban terletak di Desa Upe, Kecamatan Bonti yang berada di wilayah administrasi pemerintahan Kabupaten Sanggau provinsi Kalimantan Barat (Gambar1). Secara geografis, wilayah ini terletak pada koordinat dengan garis lintang $0^{\circ} 21^{\prime} 37.14^{\prime \prime}$ dan garis bujur $110^{\circ} 32^{\prime} 1.88^{\prime \prime}$. Bagian utara berbatasan dengan Desa Bonti, pada bagian Selatan berbatasan dengan Desa Maringin Jaya dan Desa Dosan Kecamatan Parindu, sedangkan pada bagian Timur berbatasan dengan Desa Bahta Kecamatan Bonti dan pada bagian Barat berbatasan dengan Desa Kampuh Kecamatan Bonti (Data Monografi Desa Upe, 2017).

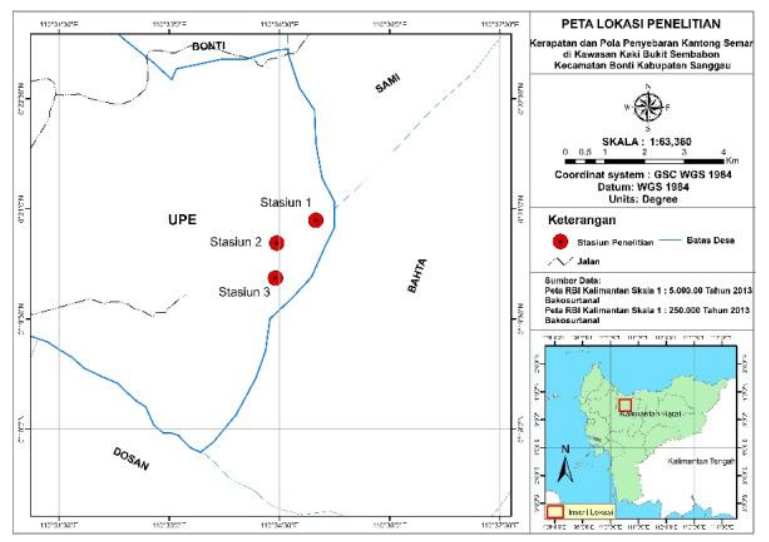

Gambar 1. Peta Lokasi Penelitian

\section{Alat dan Bahan \\ Alat-alat yang digunakan pada penelitian ini adalah,Global Positioning System (GPS)}

garmin 60, gunting, kamera pocket, kantong plastik packing, kompas, meteran gulung, Lux meter, parang, pancang, penggaris, pisau/cutter, soil tester, termometer, higrometer, dan tali rafia.

Bahan-bahan yang digunakan pada penelitian ini yaitu buku tulis, buku indentifikasi Kantong Semar, pensil, dan tabel character state.

\section{Prosedur Kerja}

\section{Penentuan Titik Sampling}

Penentuan titik sampling pada penelitian ini dilakukan secara purposive sampling berdasarkan lokasi keberadaaan kantong semar. Penentuan lokasi sampling dilakukan berdasarkan hasil survei lapangan yang diperoleh sebanyak tiga lokasi. Lokasi tersebut adalah di Dusun Lanong (lokasi I) dengan tipe vegetasi perkebunan karet, Dusun Kelompu (lokasi II) dengan tipe vegetasi hutan sekunder (Tembawang) dan Dusun Kadak (lokasi III) berada pada aliran sungai. Ketiga lokasi tersebut terletak di Desa Upe, Kecamatan Bonti, Kabupaten Sanggau.

\section{Pengambilan Data}

Proses pengambilan sampel dilakukan pada wilayah transek dengan metode sistematik sampling. Plot pengamatan dibuat dengan ukuran masing masing $20 \mathrm{~m}$ x $20 \mathrm{~m}$ sebanyak 5 plot dalam satu transek. Setiap plot pengamatan dibuat subplot pengamatan berukuran $2 \mathrm{~m}$ x $2 \mathrm{~m}$ sebanyak 5 kali ulangan (Suin, 2003). Jenis Kantong semar yang telah ditemukan selanjutnya dilakukan pengamatan karakteristiknya meliputi batang, daun, kantong, dan bunga. Kemudian lokasi ditemukannya Kantong Semar dan data hasil pengamatan karakteristik dicatat.

\section{Pengukuran Faktor Lingkungan}

Pengukuran faktor lingkungan meliputi pengukuran suhu udara, kelembaban tanah dan udara, $\mathrm{pH}$ tanah dan intensitas cahaya.

\section{Identifikasi}

Identifikasi dilakukan dengan menyesuaikan karakteristik dari Nepenthes yang telah berhasil didata menggunakan kunci determinasi dari beberapa referensi (Philip dan Lamb, 1996; Clarke, 1997; Edward, 2005; 
Untung et all., 2006; dan Listiawati dan Siregar, 2008).

\section{Analisis Data}

Analisis data diantaranya adalah pengukuran Nilai Kerapatan, Kerapatan Relatif, Frekuensi, Frekuensi Relatif, Indeks Nilai Penting, dan Pola Distribusi Nepenthes spp.

\section{Hasil dan Pembahasan}

Hasil penelitian Nepenthes di Kawasan Kaki Bukit Hutan Sebomban, Kecamatan Bonti, Kabupaten Sanggau diperoleh tiga jenis Nepenthes yaitu, Nepenthes mirabilis, Nepenthes gracilis dan Nepenthes ampullaria. Berikut ini jenis dan jumlah individu Nepenthes yang ditemukan pada masing-masing lokasi penelitian (Tabel 1 - Tabel 6)

Tabel 1. Jenis dan jumlah individu Nepenthes yang di temukan pada lokasi penelitian.

\begin{tabular}{lrrrr}
\hline \multirow{2}{*}{ Nama } & \multicolumn{2}{c}{ Lokasi Pengamatan } & \multirow{2}{*}{$\begin{array}{c}\text { Jumlah } \\
\text { individu }\end{array}$} \\
\cline { 2 - 4 } N. ampullaria & I & II & III & 15 \\
N. mirabilis & 16 & 6 & 6 & 65 \\
N. gracilis & 12 & - & - & 28 \\
\hline Jumlah & 51 & 21 & 33 & 12 \\
\hline
\end{tabular}

Jumlah N. mirabilis pada lokasi I ditemukan sebanyak 16 individu, N. gracilis ditemukan sebanyak 12 individu, dan $N$. ampullaria ditemukan sebanyak 23 individu. Pada lokasi II N. mirabilis ditemukan sebanyak 6 individu, $N$. ampullaria ditemukan sebanyak 15 individu sedangkan $N$. gracilis tidak ditemukan pada lokasi tersebut. Pada lokasi III $N$. mirabilis ditemukan sebanyak 6 individu, $N$. ampullaria ditemukan sebanyak 27 sedangkan $N$. gracilis tidak ditemukan pada lokasi ini.

Tabel 2. Nilai Kerapatan dan Kerapatan Relatif Nepenthes spp pada lokasi penelitian

\begin{tabular}{lcccccc}
\hline \multicolumn{1}{c}{$\begin{array}{c}\text { Nama } \\
\text { Spesies }\end{array}$} & \multicolumn{2}{c}{ Lokasi I } & \multicolumn{2}{c}{ Lokasi II } & \multicolumn{2}{c}{$\begin{array}{c}\text { Lokasi } \\
\text { III }\end{array}$} \\
\cline { 2 - 7 } & $\mathrm{K}$ & $\begin{array}{c}\mathrm{KR} \\
(\%)\end{array}$ & $\mathrm{K}$ & $\begin{array}{c}\mathrm{KR} \\
(\%)\end{array}$ & $\mathrm{K}$ & $\begin{array}{c}\mathrm{KR} \\
(\%)\end{array}$ \\
\hline$N$. & 38 & 45 & 25 & 71 & 45 & 82 \\
ampullaria & & & & & & \\
$N$ mirabilis & 27 & 31 & 10 & 29 & 10 & 18 \\
$N$. gracilis & 20 & 24 & - & - & - & - \\
\hline Jumlah & 84.99 & 100 & 35 & 100 & 55 & 100 \\
\hline
\end{tabular}

Tabel 4.2 menunjukan bahwa Nilai Kerapatan jenis Nepenthes spp. berkisar antara 10-45 Ind/ha dan nilai Kerapatan Relatif berkisar antara $18 \%-82 \%$.

Tabel 3. Nilai Frekuensi dan Frekuensi Relatif Nepenthes spp. Di Lokasi Penelitian

\begin{tabular}{lcccccc}
\hline \multicolumn{1}{c}{$\begin{array}{c}\text { Nama } \\
\text { Spesies }\end{array}$} & \multicolumn{2}{c}{ Lokasi I } & \multicolumn{2}{c}{ Lokasi II } & \multicolumn{2}{c}{ Lokasi III } \\
\cline { 2 - 7 } & F & $\begin{array}{c}\text { FR } \\
(\%)\end{array}$ & F & $\begin{array}{c}\text { FR } \\
(\%)\end{array}$ & F & $\begin{array}{c}\text { FR } \\
(\%)\end{array}$ \\
\hline $\begin{array}{l}N . \\
\text { ampullaria }\end{array}$ & 0.6 & 41 & 0.33 & 62.5 & 0.13 & 40 \\
$\begin{array}{l}N . \\
\text { mirabilis }\end{array}$ & 0.6 & 41 & 0.2 & 37.5 & 0.2 & 60 \\
$N$. gracilis & 0.26 & 18 & - & - & - & - \\
\hline Jumlah & 1.46 & 100 & 0.53 & 100 & 0.33 & 100 \\
\hline
\end{tabular}

$N$. mirabilis dan $N$. ampullaria pada lokasi I, II dan III memiliki nilai frekuensi yang sama yaitu sebesar 0.6. Sedangkan N. gracilis di lokasi I memiliki nilai 0.26 dan tidak ditemukan pada lokasi II dan III. $N$. ampullaria pada lokasi II memiliki nilai frekuensi relatif tertinggi sebesar $62.5 \%$ dan $N$. gracilis pada lokasi I memiliki nilai frekuensi relatif terendah yaitu sebesar $18 \%$.

Tabel 4. Indeks Nilai Penting Nepenthes spp. Lokasi Penelitian

\begin{tabular}{lrrr}
\hline \multirow{2}{*}{$\begin{array}{c}\text { Nama } \\
\text { Spesies }\end{array}$} & \multicolumn{3}{c}{ Indeks Nilai Penting } \\
\cline { 2 - 4 } & Lokasi I & Lokasi II & Lokasi III \\
\hline$N$. & 86 & 134 & 122 \\
ampullaria & & & \\
$N$. gracilis & 72 & 66 & 78 \\
$N$. gracilis & 42 & - & - \\
\hline Jumlah & 200 & 200 & 200 \\
\hline
\end{tabular}

Indek Nilai Penting di Kaki Bukit Sebomban memiliki kisaran nilai antara $42 \%$ 134\%. N. ampullaria pada lokasi III memiliki Indeks Nilai Penting tertinggi sebesar $134 \%$ dan N. mirabilis pada lokasi I memiliki Indeks Nilai Penting terendah yaitu sebesar $42 \%$.

Tabel 5. Pola Penyebaran Nepenthes spp. di Lokasi Penelitian

\begin{tabular}{rlcc}
\hline $\begin{array}{c}\text { Lokasi } \\
\text { pengamatan }\end{array}$ & $\begin{array}{c}\text { Nama } \\
\text { spesies }\end{array}$ & $\begin{array}{c}\text { Indeks } \\
\text { Morisita }\end{array}$ & $\begin{array}{c}\text { Pola } \\
\text { Penyebaran }\end{array}$ \\
\hline 1 & $\begin{array}{l}\text { N. } \\
\text { ampullaria }\end{array}$ & 1.6 & Mengelompok \\
& & &
\end{tabular}




\begin{tabular}{|c|c|c|c|}
\hline & $\begin{array}{l}N . \\
\text { mirabilis }\end{array}$ & 1.4 & Mengelompok \\
\hline & N. gracilis & 1.1 & Mengelompok \\
\hline \multirow[t]{2}{*}{2} & $\begin{array}{l}N . \\
\text { ampullaria }\end{array}$ & 1.5 & Mengelompok \\
\hline & $\begin{array}{l}N . \\
\text { mirabilis }\end{array}$ & 0.6 & Mengelompok \\
\hline \multirow[t]{2}{*}{3} & $\begin{array}{l}N . \\
\text { ampullaria }\end{array}$ & 3 & Mengelompok \\
\hline & $\begin{array}{l}N . \\
\text { mirabilis }\end{array}$ & 3 & Mengelompok \\
\hline
\end{tabular}

Pola penyebaran $N$. mirabilis, $N$. gracilis dan $N$. ampullaria pada ketiga lokasi memiliki pola penyebaran yang sama yaitu mengelompok.

Tabel 6. Pengukuran faktor Lingkungan di Lokasi Penelitian

\begin{tabular}{|c|c|c|c|}
\hline Parameter & $\begin{array}{c}\text { Lokasi } \\
1\end{array}$ & $\begin{array}{l}\text { Lokasi } \\
2\end{array}$ & Lokasi 3 \\
\hline Suhu udara $\left({ }^{\circ} \mathrm{C}\right)$ & 28.8 & 30.7 & 28.6 \\
\hline $\begin{array}{l}\text { Kelembaban Udara } \\
(\%)\end{array}$ & 76.6 & 80.6 & 80.3 \\
\hline pH Tanah & 7.0 & 6.8 & 6.6 \\
\hline $\begin{array}{l}\text { Kelembaban Tanah } \\
(\%)\end{array}$ & 48.3 & 37.3 & 38.6 \\
\hline $\begin{array}{l}\text { Intensitas Cahaya } \\
\text { (Lux) }\end{array}$ & 443.6 & 496 & 597.6 \\
\hline
\end{tabular}

dilakukan pada masing-masing lokasi penelitian. Parameter lingkungan yang diukur antara lain suhu udara, kelembaban udara, $\mathrm{pH}$ tanah, kelembaban tanah dan intensitas cahaya.

\section{Jenis-Jenis Nepenthes}

Berdasarkan hasil penelitian yang telah dilakukan di Kaki Bukit Sebomban, Kecamatan Bonti, Kabupaten Sanggau. Total jenis kantong semar yang ditemukan terdapat 3 (tiga) jenis, yaitu Nepenthes ampullaria, Nepenthes mirabilis dan Nepenthes gracilis Kantong semar yang ditemukan pada tipe vegetasi perkebunan di lokasi I sebanyak 3 jenis kantong semar, yaitu $N$. mirabilis, $N$. gracilis dan N.ampullaria, sedangkan jenis kantong semar yang ditemukan pada lokasi II dengan tipe habitat vegetasi rivarian dan lokasi III dengan tipe vegetasi hutan sekunder terdapat 2 jenis, yaitu N. mirabilis dan N. ampullaria, (Tabel 1.)

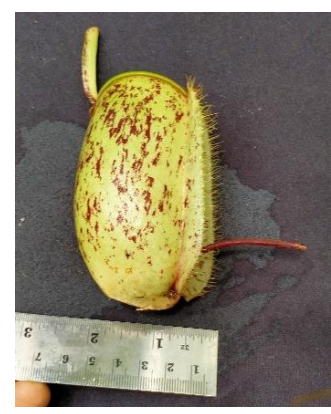

Gambar 2. Nepenthes ampullaria

Nepenthes ampullaria (Gambar 2.) memiliki bentuk kantong yang unik yang menyerupai tempayan/ bulat telur dengan tutup kantong berbentuk elips. Nepenthes ampullaria memiliki warna kantong yang bervariasi diantaranya berwarna hijau, hijau dengan lurik hitam, merah, merah dengan lurik cokelat. Daun N. ampullaria berwarna hijau tua pada permukaan atas dan hijau muda pada permukaan bawahnya. Menurut Clarke (1997) Nepenthes ampullaria yang pernah ditemukan di Pulau Borneo memiliki variasi warna kantong yang sangat beragam. Warna kantong yang paling umum ditemukan adalah warna hijau pada deluruh bagian kantong dengan lurik/bercak cokelat. Varietas yang paling unik dan menarik pada Nepenthes ampullaria ini adalah yang berwarna merah dengan corak hijau pada bagian kantongnya. Nepenthes ampullaria yang ditemukan di Hutan Sebomban ini memiliki dua varian warna diantaranya memiliki warna kantong hijau dengan lurik cokelat dan warna kantong merah. Nepenthes ampullaria merupakan jenis kantong semar yang ditemukan di semua lokasi penelitian di Hutan Sebomban yang memiliki ketinggian 86- 119 mdpl. Hal ini diduga karena iklim di Hutan Sebomban sesuai untuk jenis ini. Keadaan ini sesuai dengan pernyataan Clarke (1997) bahwa $N$. ampullaria umumnya banyak ditemukan di lahan datar terbuka dengan ketinggian tempat 0-1000 m dpl.

Nepenthes ampullaria merupakan jenis kantong semar yang paling banyak ditemukan pada ketiga lokasi pengamatan sebanyak 65 individu. Hal ini juga sesuai dengan hasil penelitian Delyanet (2009) di Gunung Pasi Singkawang Kalimantan Barat memperoleh total 29 individu $N$. ampullaria dan Jefri (2018) di Kawasan Pelestarian Plasma Nuftah (KPPN) PT. Muara Sungai landak, Kecamatan Siantan, Kabupaten 
Mempawah memperoleh total 143 individu $N$. ampullaria. Jumlah individu $N$. ampullaria yang tinggi juga dipengaruhi oleh kondisi lingkungan yang sesuai bagi jenis ini. Menurut Soerianegara dan Indrawan (1982) dalam Suwardi (2009) menyatakan bahwa banyaknya jumlah dan jenis individu pada suatu lokasi sangat tergantung pada keadaan tempat tumbuhnya. Kondisi lingkungan di Kaki Bukit Sebomban ini sesuai bagi kehidupan $N$. ampullaria. Suhu udara di Kaki Bukit Sebomban berkisar antara $28.6^{\circ} \mathrm{C}$ hingga $30,5^{\circ} \mathrm{C}$. Keadaan ini sesuai dengan pernyataan Listiawati dan Siregar (2008) bahwa suhu udara yang baik untuk pertumbuhan Nepenthes ampullaria yaitu $14-34^{\circ} \mathrm{C}$ sedangkan menurut Mansur (2006) suhu udara yang optimal untuk Nepenthes dataran rendah adalah berkisar antara $23-31^{\circ} \mathrm{C}$. Hal ini sesuai dengan hasil penelitian Baloari (2013) bahwa $N$. ampullaria banyak ditemukan di kondisi lingkungan engan suhu berkisar antara $27^{\circ} \mathrm{C}$ hingga $32^{\circ} \mathrm{C}$.

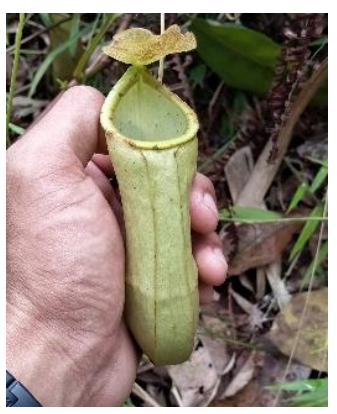

Gambar 3. Nepenthes mirabilis

Nepenthes mirabilis (Gambar 3.) yang ditemukan di Hutan Sebomban memiliki warna daun hijau tua dengan bentuk daun bulat terbalik. Bentuk batang bulat, berwarna hijau, dengan tipe percabangan monopodial. Nepenthes mirabilis memiliki bentuk kantong berbentuk pinggang pada pertengahannya dan memiliki variasi warna, yaitu berwarna hijau, hijau kekuningan, dan kemerahan. Menurut Clarke (1997) N. mirabilis merupakan jenis kantong semar yang dapat ditemukan pada ketinggian 0-1500 m dpl dan tumbuh dangan baik pada ketingiian $<500 \mathrm{~m}$ dpl. Hal ini sesuai dengan kondisi $N$. mirabilis yang ditemukan di Hutuan sebomban yang memiliki ketinggian 86-119 m dpl. N. mirabilis dan N. ampullaria pada penelitian inii ditemukan pada seluruh lokasi di Hutan Sebomban. Hal ini dikarenakan kedua jenis kantong semar ini merupakan jenis yang memiliki daya adaptasi yang tinggi (Mansur, 2006). N. mirabilis yang ditemukan di Hutan Sebomban berjumlah 28 individu. Menurut Chittenden dalam Handayani (1999) Nepenthes mirabilis umumnya dapat tumbuh pada kelembaban $60 \%-90 \%$, sedangkan menurut Listiawati dan Siregar (2008) kelembaban optimal untuk Nepenthes berkisar antara 70\%-90\%. Kondisi ini sesuai dengan kelembaban yang terdapat di Hutan Sebomban yang memiliki kelembaban $76.6 \%-80.3 \%$. Total individu Nepenthes mirabilis yang ditemukan berjumlah 28 individu.

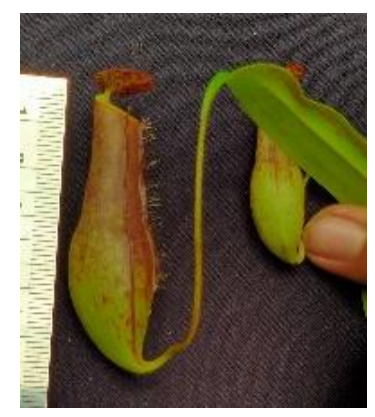

Gambar 4. Nepenthes gracilis

Berbeda dengan $N$. ampullaria dan $N$. mirabilis, N. gracilis (Gambar 4.) pada penelitian ini sedikit ditemukan dengan jumlah total individu sebanyak 12. N. gracilis hanya ditemukan pada lokasi I (Dusun Lanong) sedangkan di lokasi II dan III tidak ditemukan. Hal ini diduga kondisi vegetasi pada lokasi II dan III yang cukup rapat. Hal ini sesuai dengan pernyataan Mansur (2006) bahwa N. gracilis merupakan jenis yang lebih sering ditemukan pada tempat terbuka. $N$. gracilis yang ditemukan di Hutan Sebomban memiliki warna batang cokelat, cokelat kekuningan dengan bentuk batang bulat dan tipe percabangan monopodial dan arah tumbuh heliotrof. $N$. gracilis memiliki warna daun hijau tua pada permukaan atas dan hijau muda pada permukaan bawah. Bentuk kantong $N$. gracilis berbentuk pinggang berwarna hijau dengan lurik merah dan memiliki taji pada bagian atas pangkal penutup (Clarke, 1997). Keberadaan N. gracilis juga dipengaruhi oleh kondisi habitat hidupnya. Hal ini sesuai dengan pernyataan Indriyanto (2006) bahwa keadaan habitat tumbuh sangat mempengaruhi jumlah dan jenis individu pada suatu lokasi. Spesies ini dapat tumbuh dilantai hutan hujan tropik dataran rendah, hutan pegunungan, padang 
safana dan dapat juga bergantung pada tumbuhan lain menggunakan sulurnya (Listiawati \& Siregar, 2008).

Jumlah Nepenthes spp. yang ditemukan di Kaki Bukit Sebomban Kecamatan Bonti lebih sedikit bila dibandingkan dengan jumlah Nepenthes spp. yang ditemukan di Kawasan Taman Wisata Alam Baning Kabupaten Sintang Kalimantan Barat. Nurhadi (2018) telah menemukan 5 jenis Nepenthes spp. di Taman Wisata Alam Baning Kabupaten Sintang yaitu, Nepenthes ampullaria, Nepenthes bicalcarata, Nepenthes gracilis, Nepenthes $x$ cantleyi, dan Nepenthes mirabilis.

\section{Struktur Komunitas Nepenthes}

Berdasarkan hasil analisis data pada Tabel 2. jenis $N$. ampullaria memiliki nilai kerapatan tertinggi di 3 lokasi. Nilai kerapatan jenis $N$. ampullaria di lokasi I sebesar 38 Ind/ha, lokasi II sebesar $25 \mathrm{Ind} / \mathrm{ha}$ dan di lokasi III sebesar 45 Ind/ha. N. ampullaria pada lokasi III memiliki nilai Kerapatan Relatif tertinggi dibandingkan dengan jenis kantong semar yang lainnya yaitu sebesar $82 \%$. Sedangkan jenis $N$. mirabilis memiliki nilai kerapatan terendah pada lokasi II dan III yaitu sebesar $10 \mathrm{Ind} / \mathrm{ha}$ dan nilai Kerapatan Relatif terendah sebesar $18 \%$ pada lokasi III (Tabel 2.). N. ampullaria pada lokasi II memiliki nilai frekuensi tertinggi sebesar 0.33 Sedangkan jenis $N$. gracilis di lokasi I memiliki nilai frekuensi relatif terendah yaitu sebesar $18 \%$ dan tidak ditemukan pada lokasi II dan III.

Tingginya nilai kerapatan dan frekuensi kantong semar jenis $N$. ampullaria pada lokasi penelitian di Kaki Bukit Sebomban yang memiliki ketinggian $86 \mathrm{~m}$ dpl menunjukan bahwa kondisi habitat dan lingkungan mendukung pertumbuhan kantong semar jenis ini. Lokasi I ini memiliki ketinggian 86-119 m dpl. Berdasarkan ketinggian hidupnya tersebut, $N$. ampullaria dapat dikelompokkan dalam Nepenthes dataran rendah $(<500 \mathrm{mdpl})$. Hal ini ditegaskan oleh Anwar et al. (2007) bahwa Nepenthes dibagi menjadi tiga kelompok berdasarkan ketinggian tempat atau habitat tumbuhnya, yaitu Nepenthes dataran rendah ( $<500 \mathrm{~m} \mathrm{dpl}$ ), Nepenthes dataran menengah (500-1000 mdpl), dan Nepenthes dataran tinggi $(>1000 \mathrm{~m} \mathrm{dpl})$. Hasil pengukuran parameter lingkungan di lokasi I ini didapatkan suhu udara sebesar $26.8^{\circ} \mathrm{C}$, kelembaban udara $84 \%, \mathrm{pH}$ tanah 7.5, kelembaban tanah $90 \%$ dan intensitas cahaya 791 Lux (Tabel 6.). Hasil penelitian ini hamper sama dengan hasil yang melaporkan bahwa kantong semar dataran rendah umumnya hidup pada kisaran suhu $20-35^{\circ} \mathrm{C}$ dengan kelembaban udara yang tingi yaitu $>70 \%$ (Mansur, 2006)

Tinggi rendahnya nilai Kerapatan, Kerapatan Relatif, Frekuensi dan Frekuensi Relatif tergantung pada jumlah individu suatu jenis yang ditemukan di lingkungannya. Tinggi rendahnya jumlah individu jenis ditentukan pula oleh kondisi lingkungan/habitat dan kemampuan adaptasi suatu jenis. Hal ini sesuai dengan pernyataan Indriyanto (2006) bahwa tinggi rendahnya jumlah dan jenis individu bergantung pada kondisi habitat dan kemampuan adaptasi suatu jenis di lingkungannya. Semakin tinggi kemampuan suatu jenis untuk beradaptasi dengan lingkungannya maka semakin banyak pula jumlah individu tersebut, sebaliknya apabila kemampuan adaptasinya rendah maka semakin rendah pula jumlah suatu individu dalam habitatnya (Sumarhani dan Kalima, 2015).

Hasil analisis data pada Tabel 4 . memperoleh Indeks Nilai Penting dari ketiga lokasi pengamatan di Kaki Bukit Sebomban dengan yang berbeda-beda pada tiap jenis dan lokasinya. Indeks Nilai Penting tertinggi terdapat pada lokasi III sebesar $134 \%$ dengan jenis kantong semar yang ditemukan adalah $N$. ampullaria sedangkan $N$. gracilis yang ditemukan di lokasi I memiliki Indeks Nilai Penting terendah yaitu sebesar $42 \%$. Tingginya Indeks Nilai Penting $N$. ampullaria ini dikarenakan oleh kemampuan adaptasi yang baik dan didukung oleh kondisi lingkungan/habitat yang memungkinkan. Hal ini ditegaskan oleh Odum (1996) yang menyatakan bahwa organisme dikendalikan di alam oleh jumlah dan keragaman material yang diperlukan oleh kehidupannya serta batas toleransi organisme tersebut terhadap komponen lingkungannya.

\section{Pola Penyebaran Nepenthes}

Pola penyebaran mengelompok yang dimiliki oleh jenis $N$. mirabilis, $N$. gracilis dan $N$. ampullaria diduga di karenakan oleh faktor yang mendukung untuk hidup berkelompok seperti pola reproduksi baik secara generatif maupun 
secara vegetatif serta kondisi habitat. Menurut Odum (1996), pengelompokkan pada tumbuhan merupakan berkumpulnya individu-individu yang diakibatkan oleh tiga hal yaitu adanya perubahan cuaca harian dan musiman, adanya perbedaan habitat setempat dan proses reproduktif dari tumbuhan itu sendiri. Pola penyebaran mengelompok paling umum terdapat di alam, terutama pada tumbuhan. Menurut Barbour et al (1987), penyebaran mengelompok terjadi karena kondisi lingkungan jarang yang seragam, meskipun pada area yang sempit. Perbedaan kondisi tanah dan iklim pada suatu area akan menghasilkan perbedaan habitat yang penting bagi setiap organisme yang ada di dalamnya, karena suatu organisme aka ada pada suatu habitat yang faktor-faktor ekologinya tersedia dam sesuai bagi kehidupannya.

Menurut Michael (1990), pola penyebaran mengelompok pada Nepenthes juga dipengaruhi oleh pola reproduksi atau perkembangbiakkannya. Pola distibusi mengelompok disebabkan oleh reproduksi vegetative dan generatif. Nepenthes dapat bereproduksi secara generatif dengan biji. Biji Nepenthes berbentuk benang dan diselubungi kulit yang berbentuk kapsul serta mempunyai sayap yang panjangnya mencapai $30 \mathrm{~mm}$, namun sangat tipis. Benih yang terlepas akan terbawa oleh angin. Biji-biji Nepenthes tersebut akan jatuh dan tumbuh tidak jauh dari induknya. Hal ini dipengaruhi oleh pohon-pohon yang ada disekitarnya yang membatasi gerak penyebaran biji. Selain reproduksi secara generatif, Nepenthes juga bereproduksi secara vegetatif dengan cara pembentukan tunas. Batang Nepenthes yang tumbuh menjalar dibawah tanah dan pada bagian nodus akan tumbuh akar sehingga membentuk individu baru. Kondisi ini memnyebabkan Nepenthes akan hidup secara mengelompok pada suatu daerah tertentu.

\section{Pengukuran Faktor Lingkungan di Lokasi Penelitian}

Pengukuran suhu udara di lokasi penelitian didapatkan berkisar $28.6^{\circ}-30.7^{\circ} \mathrm{C}$. Suhu tertinggi yaitu di lokasi II sebesar $30.7^{\circ} \mathrm{C}$ dan suhu terendah terdapat di lokasi I yaitu sebesar $28.6^{\circ} \mathrm{C}$. Tinggi rendahnya suhu pada setiap lokasi pengamatan tidak berbeda jauh, hal ini dikarenakan pengambilan data dilakukan pada siang hari dengan kondisi cuaca yang cerah. Hal ini sesuai dengan hasil penelitian Delyanet (2009) yang memperoleh Nepenthes spp. pada kisaran suhu $25.7-34.3^{\circ} \mathrm{C}$. Menurut Mansur (2006) Kantong semar dataran rendah umumnya hidup pada kisaran suhu $20-35^{\circ} \mathrm{C}$, sedangkan jenis dataran tinggi pada suhu $10-30^{\circ} \mathrm{C}$ hal ini menunjukkan bahwa nilai suhu pada lokasi pengamatan di Kaki Bukit sebomban ini masih berada dalam batas normal untuk kehidupan Nepenthes.

Hasil pengukuran kelembaban Tanah pada semua lokasi pengamatan di Kaki Bukit Sebomban berkisar antara 37.3\%- $48.3 \%$ sedangkan hasil pengukuran Kelembaban Udara berkisar antara 76.6 - 80.6\% (gambar 6.). Nilai Kelembaban Tanah tertinggi terdapat pada lokasi I yaitu sebesar $48.3 \%$ dan nilai kelembaban tanah terendah terdapat pada lokasi III yaitu sebesar $37.6 \%$. Nilai kelembaban udara tertinggi terdapat pada lokasi II yaitu sebesar $80.6 \%$ dan nilai kelembaban udara terendah terdapat pada lokasi I yaitu sebesar $76.6 \%$. Dari hasil pengukuran Kelembaban udara sesuai dengan pernyataan Mansur (2006) bahwa kelembaban udara yang tinggi (>70\%) merupakan syarat penting bagi kantong semar untuk tumbuh dengan baik. Jika kelembaban terlalu rendah, dipastikan kantong semar tidak akan membentuk kantong dan tumbuhan ini tidak akan tumbuh dengan baik.

Hasil pengukuran $\mathrm{pH}$ tanah di masingmasing lokasi pengamatan berkisar antara 6.6 7.0 Nilai $\mathrm{pH}$ Tanah tertinggi terdapat pada lokasi I yaitu sebesar 7.0, sedangkan nilai $\mathrm{pH}$ Tanah terendah terdapat pada lokasi III yaitu sebesar 6.6. Hal ini sesuai dengan hasil penelitian Listiawati dan Siregar (2008) bahwa Nepenthes biasanya tumbuh pada kisaran $\mathrm{pH}$ tanah 5-7.

Hasil pengukuran intensitas cahaya di masing-masing lokasi pengataman berkisar antara 473 - 791 Lux. Berdasarkan hasil pengukuran intensitas cahaya pada masingmasing lokasi pengamatan didapatkan nilai intensitas cahaya tertinggi terdapat di lokasi III yaitu sebesar 597.6 Lux dan nilai intensitas cahaya terendah terdapat di lokasi I yaitu sebesar 443.6 Lux. Menurut Mansur (2006), Tingkat kebutuhan kantong semar akan intensitas cahaya tergantung pada Masing-masing jenisnya. Ada jenis-jenis yang menghendaki sinar matahari secara langsung dan ada juga yang butuh sinar 
matahari secara tidak langsung. Hal ini hampir sama dengan hasil penelitian Jefri (2018) yang mendapatkan nilai intensitas cahaya berkisar antara 539.3 - 765.3 Lux.

\section{Kesimpulan}

Berdasarkan hasil penelitian yang dilakukan, dapat disimpulkan bahwa terdapat tigajenis Nepenthes yang ditemukan yaitu, Nepenthes mirabilis, Nepenthes gracilis dan Nepenthes ampullaria. Nilai Kerapatan Nepenthes spp. berkisar antara 10-45 ind/ha. Nilai frekuensi berkisar antara 0.2-0.33. Indeks Nilai penting Nepenthes spp. berkisar antara $42 \%$ - $134 \%$, dengan nilai INP tertinggi yaitu jenis Nepenthes ampullaria di lokasi III, sedangkan nilai INP terendah terdapat di lokasi I yaitu Nepenthes gracilis. Ketiga jenis Nepenthes memiliki pola penyebaran yang tergolong dalam kategori mengelompok.

\section{Ucapan Terima Kasih}

Terima kasih kepada Bapak/Ibu Dosen, Laboran, Masyarakat Desa upe, teman-teman Biologi Angkatan 2015, dan Editor yang telah membantu dalam penelitian, penulisan hingga terbitnya jurnal ini.

\section{References}

Baloari, G., Linda, R., \& Mukarlina (2013). Keanekaragaman jenis dan pola distribusi Nepenthes spp. di Gunung Semahung, Kecamatan Sengah Temila, Kabupaten Landak. Jurnal Protobiont, 2 (1):1-6. Doi:10.26418/protobiont.v2i1.1346. https://jurnal.untan.ac.id/index.php/jprb/a $\underline{\text { rticle/view/1346 }}$

Barbour, M.G.B, Jack, H. \& Pitts, WD. (1987).Terrestrial Plant, Ecology. The Benjamin Cumming Publishing Company. California.

CITES (2010). Convention on International Trade in Endangered Species Of Wild Fauna And Flora. Appendices I, II, III.
Clarke, C. (1997). Nepenthes of Borneo. Natural History Publication (Borneo). Kinibalu.

Data Monografi Desa (2017). Data dan Informasi Desa Upe. Sekterariat Desa Upe, Bonti.

Delyanet (2009). Keanekaragaman Jenis Kantong Semar (Nepenthes spp.) Di Gunung Pasi Singkawang Kalimantan Barat. [Skripsi], Jurusan Biologi Universitas Tanjungpura Pontianak. Pontianak.

Indriyanto (2006). Ekologi Hutan. PT. Bumi Aksara. Jakarta.

Mansur (2006). Nepenthes kantong semar yang unik. Penebar Swadaya, Jakarta.

Michael, P. (1990). Metode Ekologi untuk Penyelidikan Ladang dan Laboratorium. Universitas Indonesia. Jakarta, Hal 341.

Nurhadi, A. (2018). Keanekaragaman Jenis dan Pola Distribusi Kantong Semar (Nepenthes spp.) di Kawasan Taman Wisata Baning Kabupaten Sintang Kalimantan Barat. [Skripsi] Jurusan Biologi Fakultas Matematika dan Ilmu Pengetahuan Alam Universitas Tanjungpura. Pontianak.

Odum, E, P. (1996). Dasar-Dasar Ekologi. Gadjah Mada University Press. Yogyakarta.

Peraturan Pemerintah RI Nomor 7 Tahun 1999 Tentang Jenis-Jenis Tumbuhan dan Satwa yang dilindungi. Departemen Kehutanan.

Selvi, R.S., Muin A., \& Tavita G.E. (2015). Keanekaragaman Jenis Kantong Semar (Nepenthes spp.) Kawasan Hutan Lindung Gunung Ambawang Desa Kampung Baru, Kecamatan Kubu, Kabupaten Kubu Raya, Kalimantan Barat. Jurnal Hutan Lestari, 3(1), 51-57. Doi: 10.26418/jhl.v3i18898. https://jurnal.untan.ac.id/index.php/jmfkh /article/view/8898 
Septiani, O., Herawatiningsih, R. \& Manurung, T.F. (2018). Keanekargaman Jenis Kantong Semar (Nepenthes spp) Dalam Kawasan Hutan Tanaman Industri PT. Bharata Alam Lestari Kabupaten Mempawah Kalimantan Barat. Jurnal Hutan Lestari, 6(4), 733-741. Doi:10.26418/jhl.v6i4.29017. https://jurnal.untan.ac.id/index.php/jmf kh/article/view/29017

Soerianegara, I. \& Indrawan, A. (1982). Ekologi Hutan. Pusat Pendidikan Lembaga Kerjasama Fakultas Kehutanan epu. Direksi Perum Perhutani, Bogor, hal 19-50.

Suin, N, M. (2003). Metoda Ekologi. Universitas Andalas. Padang.

Sumarhani \& Kalima, T. (2015). Struktur dan Kompetisi Vegetasi Argoforestri Tembawang di Kabupaten Sanggau Kalimantan Barat. Pros Sem NasMasy Biodiv Indo, 1(5). Doi: 10.13057/psnmbi/m010522.

http://balitekagroforestry.org/btpaciadmin/content/pr osiding_Fdownload/Komisi_B_Semnas _AF_Unpad_2015.pdf

Supriatna, J.M., Indrawan, Kranadibrata \& Primack (1998). Biologi. Yayasan Obor Indonesia. Jakarta.

Suwardi, A, B. (2009). Keanekaragaman dan Pola Distribusi Kantong Semar (Nepenthes spp.) di Kawasan Hutan Rawa Gambut Desa Teluk Bakung Kecamatan Sungai Ambawang Kalimantan Barat. [Skripsi], Jurusan Biologi Fakultas Matematika dan Ilmu Pengetahuan Alam Universitas Tanjungpura, Pontianak.

Undang-Undang No. 5 tahun 1990 tentang Konservasi Sumber Daya Alam Hayati dan Ekosistemnya. 